\title{
The genetics of sexual behavior in Drosophila
}

\author{
This article was published in the following Dove Press journal: \\ Advances in Genomics and Genetics \\ 15 February 2016 \\ Number of times this article has been viewed
}

\author{
Bashisth N Singh \\ Akanksha Singh \\ Genetics Laboratory, Department of \\ Zoology, Banaras Hindu University, \\ Varanasi, India
}

\begin{abstract}
Genes play a profound role in the regulation of Drosophila behavioral system, either sexual or nonsexual. Those regulating sexual behavior may lead to differences at the level of species, thus causing behavioral isolation. Courtship in Drosophila involves several behavioral repertoires which are controlled genetically. It involves the use of several sensory stimuli that may affect the behavioral responses of both the sexes. These sensory signals are sex specific, and the specificity is due to differential expression of the genes. In addition to the premating behavior, certain candidate genes also affect several postmating responses. Genes also play a magnificent role in the differentiation of two morphologically and behaviorally distinct sexes as well as in their brain structures, which may explain the basis of sexual dimorphism in Drosophila. Also, the advancement in the area of system genetics like the use of mutants and GAL4/ UAS and CRISPR/Cas9 systems provides a much better way to understand the role of genes in controlling several aspects of behavior more closely.
\end{abstract}

Keywords: courtship, Drosophila, system genetics, sexual behavior, pheromones, sexual dimorphism

\section{Introduction}

Sex differences in behavior are prevalent among the animal kingdom. It is generally believed that behavior acquires such differences because the sensory system of males and females receives external and internal signals differently. It has also been a matter of controversy how the genes shape the different aspects of behavior and how the environment modulates this process. So to answer this question, the area of behavior genetics has come forward in order to emphasize how the genes control different behavioral repertoires via nervous system. Behavior has already attained a four-dimensional array during the course of evolution, and this was understood when several studies provide evidence about the role played by the genes during the time of development. ${ }^{1}$

In the recent era, Drosophila has come up as a powerful model system for studying the neurogenetics of behavior. This is due to the presence of large number of behavioral mutants which influence several neuronal subsets that may directly or indirectly involve in executing several behavioral phenotypes. Behavior genes have a special evolutionary interest because they are potentially involved in speciation and in many forms of adaptation. Dozens of loci affecting different aspects of behavior have already been identified and cloned in Drosophila. Some of these genes determine variation in such ethologically complex phenotypes as the male "love song" that is produced during courtship and a locomotor sleep-wake activity cycle that are controlled by the circadian clock. ${ }^{2}$ Among the four different stages of Drosophila life cycle, only two

\author{
Correspondence: Bashisth N Singh \\ Genetics Laboratory, Department of \\ Zoology, Banaras Hindu University, \\ Varanasi 221005, India \\ $\mathrm{Tel}+919935345196$ \\ Email bnsingh@bhu.ac.in
}

submit your manuscript | www.dovepress.com

Dovepress

http://dx.doi.org/| 0.2147/AGG.558525
Advances in Genomics and Genetics 2016:6 1-9

(c) (1) (5) 2016 singh and Singh. This work is published and licensed by Dove Medical Press Limited. The full terms of this license are available at https://www.dovepress.com/ (c) work you hereby accept the Terms. Non-commercial uses of the work are permitted without any further permission from Dove Medical Press Limited, provided the work is properly attributed. For permission for commercial use of this work, please see paragraphs 4.2 and 5 of our Terms (https://www.dovepress.com/terms.php). 
life cycle stages have been suggested to exhibit most of the behavioral responses: larvae and adults. This is due to the presence of several literatures which provide evidence regarding the behavioral activities of both the stages. However, in the genetic context, it is not easy to understand the process of behavioral analysis since the process is multifaceted and requires deeper insight into the several wide range of those genes which act at several time points in an individual's life. The easiest modes to identify the key players executing several behavioral responses are firstly to look into those developmental genes that are interacting with each other to bring out a definite behavioral phenotype and secondly to identify those neuronal subsets which are interconnected with each other to produce definite repertoires. In view of this, behavior genetic analysis has come up as an approach to identify the role played by the genes in order to give a definite behavior system. ${ }^{3,4}$ Two kinds of behaviors have been found in the Drosophila: one is the sexual and the other is the nonsexual behavior. In this review, we are more likely to discuss about genes that play direct as well as indirect roles in the sexual behavior of Drosophila. Sexual behavior of Drosophila is among the more important of these fruit flies actions both from the organism perspective and in terms of how its nervous system can be investigated. In fact, some of the first behavioral genetic experiments in the genus Drosophila involve courtship and mating. Therefore, the main aim of this review is to discuss the evolutionary perspective of sexual behavior and to speculate how different genes control several aspects of sexual behavior. This also provides a glimpse about the usage of different tools and techniques, which help us to understand the Drosophila mating system.

\section{Courtship and pheromonal communication in Drosophila}

Mating behavior of Drosophila spp. consists of speciesspecific fixed action patterns, which are accompanied by orientation movements. It is basically divided into premating and postmating behavior. The premating behavior usually constitutes the courtship behavior, which involves mostly the exchange of different kinds of stimuli as well as mate choice, and the postmating behavior involves the remating, sperm competition, and sperm displacement. Certain genetic approaches were undertaken to study several courtship parameters in Drosophila. The first approach is to simplify the complexity of behavioral phenotype into its simplest genetic constituents and use recent molecular methods to disentangle the biochemical origin of behavior. During sexual communication, there is an exchange of certain sensory signals between the two partners, which is always in the influence of species-specific mate recognition system. ${ }^{5}$ Therefore, it is important to understand the key role played by the genes during courtship, and this could be investigated by identifying the function of those signals which are involved in species discrimination. ${ }^{6}$ In the genus Drosophila, courtship involves a series of fixed action patterns where a male performs a series of behavioral repertoires, for example, tapping, singing, licking, and bending his abdomen in order to make a contact with the genitalia of the female in order to copulate her. It has been predicted that these behavioral components are sexually selected and are conserved during the course of evolution and thereby found to be present among all the species of the genus Drosophila. ${ }^{7}$

During the course of sexual interplay, both the partners exchange several sensory cues which include visual, acoustic, olfactory, gustatory, and tactile signals. ${ }^{6}$ These signals are species specific and are important constituents of speciesspecific mate recognition system and thereby vary across the genus. ${ }^{8}$ Such kind of variations may also emphasize about the environmental restraint on the sexual communication between the two partners. For example, Drosophila auraria flies inhabit in a dark environment and do not prefer visual cues for their communication and hence utilize only chemical signals that are exchanged during their courtship interplay. These pheromonal signals are volatile in nature and can be detected from a short distance. ${ }^{9}$ Pheromones have been found to exert stimulatory as well as inhibitory effects on the Drosophila nervous system. On this basis, pheromones are classified as stimulatory and inhibitory pheromones. Stimulatory pheromones are localized on the proximal legs and inhibitory on the maxillary palps. ${ }^{10,11}$ In addition to these two pheromones, there are certain other kinds of aggression pheromones like cis-vaccenyl acetate in Drosophila melanogaster and Drosophila simulans, which show similar kinds of effects as that with the food odors and thereby attract different Drosophila spp. on the same area. ${ }^{12-14}$

\section{Genes involved in premating behavior of Drosophila}

Premating or courtship behavior of Drosophila involves several behavior repertoires. These behavior repertoires are supported by visual, auditory, and chemosensory cues, which thereby form an integral part of successful courtship. ${ }^{15-20}$ These behavioral responses contribute in the assessment of the sex and receptivity of potential partners, ${ }^{6}$ and expressing all these components in the appropriate situation and sequence increases the likelihood of mating success. Specific 
behaviors in this pattern are involved in reproductive isolation and are presumably the targets of intersexual selection, including courtship song, ${ }^{21}$ as well as latencies and durations of courtship and copulation in response to species-specific pheromonal differences. ${ }^{22}$ These forms of behaviors are governed by certain sets of genes that have a direct as well as indirect role in courtship behavior and were suggested to be involved in variations in mating preference like cacophony, white, fruitless (fru), Voila, courtless, desat as well as per, nonA/dissonance, and dissatisfaction (Table 1). Variants of fru and $d s x$ expressing in different regions of the brain involve in male-specific courtship pattern like wing song. ${ }^{23-29}$ Similarly, female-specific behaviors are also under the control of certain genes, for example, retn, spinster (spn), and chaste (chst), which regulate the behavioral response via nervous system (Table 1). ${ }^{28,30-32}$ Among them, retn and $d s x$ play a profound role in the receptivity of females and courtship activity of males. $d s x M$ decreases the courtship behavior

Table I Role of genes/chromosomes in controlling several aspects of sexual behavior of Drosophila

\begin{tabular}{|c|c|c|}
\hline $\begin{array}{l}\text { Genes/ } \\
\text { chromosomes }\end{array}$ & $\begin{array}{l}\text { Behavioral } \\
\text { phenotypes }\end{array}$ & References \\
\hline $\begin{array}{l}\text { white, fru, dsx, Voila, } \\
\text { nonA, dissatisfaction }\end{array}$ & Courtship repertoires & $23-29$ \\
\hline $\begin{array}{l}\text { cacophony and } \\
\text { dissonance }\end{array}$ & Courtship song & 29 \\
\hline Per & $\begin{array}{l}\text { Circadian rhythm and } \\
\text { locomotor activity }\end{array}$ & 45 \\
\hline $\begin{array}{l}\text { retn, spinster, chaste, } \\
d s x F\end{array}$ & $\begin{array}{l}\text { Female-specific } \\
\text { behavior }\end{array}$ & $27,28,3 I-33$ \\
\hline$d s \times M$ & $\begin{array}{l}\text { Male-specific behavior } \\
\text { and imaginal disc } \\
\text { development }\end{array}$ & $25,28,34$ \\
\hline Chromosome III & $\begin{array}{l}\text { Mate recognition } \\
\text { system }\end{array}$ & 35 \\
\hline Desat & $\begin{array}{l}\text { Pheromonal } \\
\text { communication }\end{array}$ & $30,37-40$ \\
\hline tra-2 & Sexual differentiation & 45 \\
\hline $\begin{array}{l}\text { Karyotypes } \\
\text { (ST, CH, TL, PP) }\end{array}$ & $\begin{array}{l}\text { Mating speed and } \\
\text { duration of copulation }\end{array}$ & $4 I-46$ \\
\hline $\begin{array}{l}\text { CREB, yellow, ebony, } \\
\text { hypoactive } C \text {, inactive, } \\
\text { and apterous }\end{array}$ & Female receptivity & 45,48 \\
\hline Chromosome II & Remating speed & $49-51$ \\
\hline $\begin{array}{l}\text { CGI656/I652, } \\
\text { CGI7575, CG9997, } \\
\text { Acp70A, antares, } \\
\text { aquarius, intrepid }\end{array}$ & $\begin{array}{l}\text { Increase egg laying } \\
\text { after mating and } \\
\text { decrease receptivity }\end{array}$ & $52-55$ \\
\hline $\begin{array}{l}\text { HOX, Scr, vg, dpp, } \\
\text { Distal-less, dachshund, } \\
\text { rotund }\end{array}$ & $\begin{array}{l}\text { Sexual dimorphism } \\
\text { and sex comb } \\
\text { development in male }\end{array}$ & $88-90$ \\
\hline $\begin{array}{l}\text { babl and bab2, } \\
A B D-B, D s x F\end{array}$ & Pigmentation & $33,34,91-112$ \\
\hline
\end{tabular}

of males, whereas retn plays an antagonistic effect on the courtship behavior of males by influencing the development of muscle of Lawrence. Hence, fru and $d s x$ play a combined role in regulating the function of developmental gene retn. ${ }^{33}$ In addition to this, $d s x$ and fru also have a profound effect on pre- and postcopulatory behavior via Dh44 neuron, hence regulating sperm storage and release. ${ }^{34}$ Nanda and Singh ${ }^{35}$ documented that the genes affecting the mate recognition system of Drosophila are located on the third chromosome (Table 1). Later, Gaertner et $\mathrm{al}^{36}$ found strong resemblance between several genes located on $3 \mathrm{R}$ chromosome with the courtship pattern.

Apart from visual and acoustic communication, chemical communication also plays a profound role in the Drosophila mating behavior. The cuticular hydrocarbons of Drosophila female are under the control of female-specific desaturase locus (Table 1). ${ }^{37-40}$

Chromosomal polymorphism also affects the sexual activity of Drosophila. Several studies documented the role of karyotypes in affecting the mating ability. ${ }^{41,42}$ Singh and Chatterjee ${ }^{43,44}$ found that the heterokaryotypes show higher mating propensity as compared to homokaryotypes. Later, the results of the selection experiment in different species of Drosophila suggest that the males are more prone toward selection. ${ }^{45,46}$

\section{Genes involved in postmating behavior of Drosophila}

One of the most important postcopulatory behaviors of Drosophila is remating and sperm competition. Female remating involves several postmating responses which are categorized into short-term and long-term responses. Short-term response includes increase in the egg-laying rate assisted by seminal protein ovulin, and long-term response includes decrease in the receptivity of female assisted by sex peptide. ${ }^{47}$ The cAMP-responsive transcriptional factor (CREB), is highly conserved among animal species. In D. melanogaster, one of the alternatively spliced products of $C R E B$ gene, dCREB-2, is a repressor of dCREB2-a. Sakai and Kidokora ${ }^{48}$ demonstrated that overexpression of dCREB2-b in virgin females enhances their sexual receptivity and CREB may be involved in female sexual behavior (Table 1). There are several mutations which have direct as well as indirect effect on female receptivity, and among them are yellow, ebony, hypoactive $C$, inactive, and apterous (Table 1$).{ }^{45}$ Female remating is always under polygenic control as described by Singh and Singh. ${ }^{49}$ Several models were proposed to explain the genetic basis of sperm displacement. Prout and Bundgaard ${ }^{50}$ provide evidence 
that suggests genes have a direct influence on postmating responses, but this is not the case always as many studies found no relation between chromosomal arrangements and remating rate (Table 1$){ }^{51}$

During mating, molecular contribution of males as well as females is required. Males provide sperm as well as seminal proteins to the female. In Drosophila, almost all the seminal proteins are made in the male accessory gland, which thereby induce several postmating responses like increase in the egg laying, sperm storage, release, and decrease in the female receptivity. ${ }^{52-54}$ Studies pertaining to evolutionary rate covariation identify three male- as well as three female-expressed candidate genes that are required in eliciting postmating responses (Table 1). ${ }^{55}$

Several studies pertaining to genetic bases of sperm competition ability suggest a close association between polymorphism of several accessory gland protein loci and the number of progeny produced by first and second male after remating. ${ }^{56-58}$

\section{Genetic basis for sexual dimorphism}

Sexual dimorphism is defined as the differentiation in the reproductive traits between males and females. It can usually be explained on the basis of sex linkage and/or genotypesex interactions (exclusive of sex linkage). The distinction between these two mechanisms is particularly difficult to assess in the case of quantitative traits that show different degrees of development in males and females. Darwin ${ }^{59}$ explained the phenomena of sexual dimorphism in the context of intersexual selection by taking the example of peacock whose long feathers attract peahen which has comparatively short feathers. Two prerequisites must be met for the evolution of sexual dimorphism. First, the intersex genetic correlation must be less than one, ${ }^{60,61}$ indicating that genetic variation exists for the independent evolution of the trait in each sex. Second, the strength of natural and/or sexual selection acting on the trait in each sex must be different, ${ }^{62}$ resulting in a net selection differential between the sexes. The development of a trait in one sex and not the other must be the result of differential gene expression. Correlations have been found between gene expression patterns and dimorphic trait production. For example, msxC expression is associated with the development of the male "sword" of the sword tail fish. ${ }^{63}$ Only relatively few investigations have specifically considered the evolution of sexual dimorphism, covering a wide range of study systems including the skull in primates, ${ }^{64-67}$ body properties of lizards, ${ }^{68,69}$ newts, ${ }^{70}$ the head shape of Chironomous larvae, ${ }^{71}$ and lycium flowers and insects including
Drosophila. Examples of sexual dimorphism in Drosophila include abdominal bristle number, abdominal tip pigmentation in males and females, sex comb pattern of males, brain differentiation of male and female, body size, shape, and genital architecture.

In the genus Drosophila, both the sexes exhibit differences in several aspects of behavior. ${ }^{61-74}$ In D. melanogaster, $15 \%-$ $70 \%$ of known genes have sexually dimorphic expression. ${ }^{75-78}$ In several animals, sexual dimorphism is not only restricted to reproductive organs but also present in certain morphological structures. Most animals demonstrate characteristics of sexual dimorphism for body size. Male mammals are usually larger than females. Substantial progress has been made in order to elucidate the physiological and environmental factors that are involved in the differences in body size. Carriera et a ${ }^{79}$ studied the effect of candidate gene mutation on the body size of $D$. melanogaster males and females. The results of their study suggest that the mutations affect the body size of the males and the females reversibly. Patterns of chromosome inversions also favor the body size dimorphism as reported by Taylor et $\mathrm{a}^{80}$ in Drosophila pseudoobscura.

In addition to body size, there is another most important sexual dimorphic character, the sex comb of Drosophila. It is one of the most evolved structures and present in the melanogaster, obscura, fima, and dentissima species groups. ${ }^{81-85}$ Variations in the orientation of sex comb as well as sex comb tooth number exist among different species of Drosophila. ${ }^{86,87}$ Several studies pertaining to sex comb depict the roles of $H O X$ and Scr genes in the development of this morphological structure. Scr deficiency causes reduction in the number of sex combs, and $S c r$ duplication increases the number of sex comb teeth. ${ }^{88,89}$ These temperature-sensitive $S c r$ alleles are required for sex comb development during the third instar stage. ${ }^{90}$ Similarly, the two specific isoforms $d s x M$ and $d s x F$ act differently in the development of male- and femalespecific structures (Table 1) ${ }^{91-96}$ Both the isoforms of $d s x$ act antagonistically on different targets present on multiple tissues with one being a positive regulator of certain gene in one tissue while negative regulator in others and vice versa. ${ }^{97}$ Several other genes also play a role in the development of sex comb, for example, wg, dpp, Distal-less (DII), dachshund (dac), rotund (rn), and bric-a-brac (bab) (Table 1). ${ }^{97,98}$

Various types of pigmentation variations within and between closely related species are observed in many insect taxa as well as in Drosophila spp. ${ }^{99-103}$ Among them, an intriguing point one would notice is the existence of numerous reports on closely related species pairs with contrasting appearances in terms of body pigmentation intensity. Those cases 
include species pairs, Drosophila ananassae-Drosophila pallidosa, ${ }^{104}$ Drosophila yakuba-Drosophila santomea, ${ }^{105}$ Drosophila malerkotliana malerkotliana-Drosophila malerkotliana pallens, ${ }^{106}$ Drosophila pseudoananassae pseudoananassae-Drosophila pseudoananassae nigrens, Drosophila bipectinata-Drosophila parabipectinata, ${ }^{106}$ and Drosophila novamexicana-Drosophila americana. Actually, D. novamexicana is distinctively pale compared to other Drosophila virilis group species. ${ }^{107}$ These species pairs have divergence time short enough that ability to interbreed has allowed genetic analyses and has helped narrowing down or to identify responsive genetic changes underlying the pigmentation differences. ${ }^{102,106-108}$ Males of this group show darkly pigmented dorsal cuticular tergites, while in females, pigmentation is restricted to posterior tergites. This differential pigmentation is regulated by the expression of two genes $b a b 1$ and $b a b 2$ of the $b a b$ locus. ${ }^{108-110}$ However, the function of $b a b$ is under the control of female-specific $A B D-B$ and $\operatorname{DsxF}$ (Table 1). ${ }^{111,112}$

Several other genes were also found to be responsible for the abdominal pigmentation, which are transcribed and translated only at the time of development. ${ }^{102-118}$ Among different Drosophila spp. subgroups, species and subspecies in the ananassae species subgroup have darkly pigmented abdominal tip, while others lack completely. In many species of the melanogaster group, abdominal pigmentation is sexually dimorphic with the last two or three segments completely covered by dark melanin in males and not in females. Although sex-specific pigmentation is fixed in the closest relative of $D$. melanogaster, it is highly variable in the more basal ananassae species subgroup where some species and subspecies have dark male abdominal pigmentation, while others lack it completely. ${ }^{119}$ Wing spot in certain species of Drosophila has put forward a very good example in order to explain the phenomenon of sexual dimorphism in this genus. The wing spot in Drosophila has been evolved from the regulatory network of some novel genes and is regulated at the transcriptional level by the cis-regulatory elements of yellow pigmentation gene. ${ }^{120}$ Experiments pertaining to mating behavior in this species suggest a greater mating success of the males with black wing spot as compared to the males without spot. These studies suggest the role of wing spot during courtship and thereby provide an excellent example of the adaptive function of pigmentation and its diversification. ${ }^{121}$ Recently, Takahashi ${ }^{122}$ has discussed the pathway underlying the biochemical basis of pigmentation variation in different Drosophila spp. Yassin and Orgogozo ${ }^{123}$ found that there are several new female-specific genital structures that coevolve with male genital structures providing a very good example of sexual dimorphism at the postcopulatory level.

\section{Tools and techniques to analyze several behavioral paradigms: an approach to system genetics}

As it is already discussed, Drosophila is one of the best model systems to understand neurogenetics of behavior. This is due to simple and sophisticated sets of genetic tools and techniques. One of the most important and easiest modes to analyze the behavioral defects is the use of behavioral mutants. Mutants have been supported by several behavioral biologists as an approach to understand the complexity of the behavioral system. For example, a known mutant in the genus Drosophila is fru, which disrupts the male and female orientation during mating. There are two mutants like satori (sat) and he is not interested (hni) involved in homosexual courtship. ${ }^{124,125}$

A recent advancement in the Drosophila molecular genetics system is the entry of UAS/GAL4 expression system. By this system, it is easier to identify those behavioral genes that are expressed in neuronal mass in the brain and other neuronal innervations. ${ }^{126-130}$ Some other advantages of this system are 1) identification of genes by making use of enhancer trap mechanism, 2) targeted knockdown of gene of interest to produce RNAi lines of that corresponding gene, and 3) screening of mutations affecting a certain known phenotype. Thus, this system helps us to provide a way to observe several behavioral phenotypes.

In the recent era, technologies like optogenetics and thermogenetics have made possible the identification of certain genes, which directly affect courtship stimuli. One such discovery in the field of thermogenetics is the use of the thermosensitive channel TrpA1 to activate neurons expressing fru, a major courtship regulator gene, and thereby induce most of the elementary courtship acts in a solitary male exposed to temperature increase. The TrpA1 flies are mostly activated at $29^{\circ} \mathrm{C}$, and temperature-sensitive behavioral response can be easily analyzed and corresponding genes will be identified through GAL4 system. ${ }^{131,132}$ The area of optogenetics helps in visualizing any phenotype misexpression in Drosophila eyes. This utilizes the GMR-GAL4 in order to create visual defects and thereby makes easier the analysis of behavioral responses due to such type of disruptions. ${ }^{133}$

More recent advancement in fly genetics is the use of synthetic nuclease technologies, especially the CRISPR/Cas9 system. Application of these new genome-editing approaches in Drosophila will modernize our understanding to analyze 
the function of gene in the near future. Several groups have used the CRISPR/Cas9 system to induce targeted mutations in Drosophila ${ }^{134-139}$ but differed in their approach to supplying the Cas9 protein and sgRNA components of the system. Synthetic nucleases are programmable nucleases that can be directed to cleave a specified sequence in the genome and thereby provide different knockout lines of Drosophila. The simplicity at which it can be reprogrammed to target different sites will also enable large-scale application of this genomewide technology, to allow more powerful reverse genetic analyses, and allow us to more easily study combinations of any type of behavior-based mutations.

\section{Conclusion}

D. melanogaster has proven to be a wonderful model system to understand the genetic basis of sexual behavior. This is due to the presence of small number of chromosomes as well as availability of several mutants that makes understanding of behavior genetics of Drosophila very easy. Still, there is a big question that how these genes control the sex specificity of behavior during the time of development. However, it has been observed that the behavioral genes have a wide range of functions. Therefore, it is very much necessary to understand those complex networks which have direct role with the behavioral genes. Also, the recent advancement in the areas of optogenetics and thermogenetics and the development of different tools/ technologies like GAL4/UAS system has made any kind of behavior genetic analysis very easier. And the use of CRISPR/ Cas9 method to generate any kind of single point mutations helps in understanding numerous aspects of behavior.

Therefore, the main aim of this review is to summarize certain aspects of behavior of Drosophila which are under the genetic and nervous regulation.

\section{Acknowledgments}

Financial support in the form of UGC-BSR faculty fellowship to BNS and Meritorious fellowship to AS from the UGC, New Delhi, is gratefully acknowledged. The authors also thank the Editor-in-Chief and two anonymous reviewers for their helpful comments and suggestions on the original draft of the manuscript.

\section{Disclosure}

The authors report no conflicts of interest in this work.

\section{References}

1. Singh SR, Singh BN, Hoenigsberg HF. Female remating, sperm competition and sexual selection in Drosophila. Genet Mol Res. 2002;1:178-215.
2. Peixoto AA. Evolutionary behavioral genetics in Drosophila. Adv Genet. 2002;47:117-150.

3. Carpenter FW. The reactions of the pomace fly (Drosophila ampelophila Loew) to light, gravity and mechanical stimulation. Am Nat. 1905;39:157-171.

4. Pavlou HJ, Goodwin SF. Courtship behavior in Drosophila melanogaster: towards a 'courtship connectome'. Curr Opin Neurobiol. 2013;23:76-83.

5. Paterson HE. A comment on 'mate recognition systems'. Evolution. 1980;34:330-331.

6. Greenspan RJ, Ferveur JF. Courtship in Drosophila. Annu Rev Entomol. 2000;34:205-232.

7. Villella A, Hall JC. Courtship anomalies caused by doublesex mutations in Drosophila melanogaster. Genetics. 1996;143:331-344.

8. Marcillac F, Ferveur JF. A set of female pheromones affects on reproduction before, during and after mating in Drosophila. J Exp Biol. 2004;207:3927-3933.

9. Oguma Y, Jallon JM, Tomaru M, Matsubayashi H. Courtship behaviour and sexual isolation between Drosophila auraria and D. triauraria in darkness and light. J Evol Biol. 1996;9:803-815.

10. Stocker RF, Gendre N. Courtship behavior of Drosophila, genetically and surgically deprived of basiconic sensilla. Behav Genet. 1989;19:371-385.

11. Venard R, Antony C, Jallon JM. Drosophila chemoreceptors. In: Singh RN, Strausfeld JS, editors. Neurobiology of Sensory Systems. New York: Plenum; 1989:377-385.

12. Savarit F, Sureau G, Cobb M, Ferveur JF. Genetic elimination of known pheromones reveals the fundamental chemical bases of mating and isolation in Drosophila. Proc Natl Acad Sci U S A. 1999;96:9015-9020.

13. Bartelt RJ, Schaner AM, Jackson LL. Cis-vaccenyl acetate as an aggregation pheromone in Drosophila melanogaster. J Chem Ecol. 1985;11:1747-1756.

14. Schaner AM, Bartelt RJ, Jackson LL. Z-11-Octadenyl acetate, an aggregation pheromone in Drosophila simulans. J Chem Ecol. 1987;13:1777-1786.

15. Hall JC. The mating of a fly. Science. 1994;264:1702-1714.

16. Greenspan RJ. Understanding the genetic construction of behavior. Sci Am. 1995;272:72-78.

17. Yamamoto D, Jallon JM, Komatsu A. Genetic dissection of sexual behaviour in Drosophila melanogaster. Annu Rev Entomol. 1997;42:551-585.

18. Ferveur JF. The pheromonal role of cuticular hydrocarbons in Drosophila melanogaster. BioEssays. 1997;19:353-358.

19. Sokolowski MB. Drosophila: genetics meets behaviour. Nat Rev Genet. 2001;2:879-890.

20. Markow TA. Behavioral and sensory basis of courtship success in Drosophila melanogaster. Proc Natl Acad Sci U S A. 1987;84: 6200-6204.

21. Gleason JM, Ritchie MG. Evolution of courtship song and reproductive isolation in the Drosophila willistoni species complex: do sexual signals diverge the most quickly? Evolution. 1998;52:1493-1500.

22. Civetta A, Cantor EJ. The genetics of mating recognition between Drosophila simulans and D. sechellia. Genet Res. 2003;82:117-126.

23. Anaka M, Macdonald CD, Barkova E, et al. The white gene of Drosophila melanogaster encodes a protein with a role in courtship behaviour. J Neurogenet. 2008;22:243-276.

24. Williams TM, Carroll SB. Genetic and molecular insights into the development and evolution of sexual dimorphism. Nat Rev Genet. 2009;10:797-804.

25. Kristic D, Boll W, Noll M. Sensory integration regulating male courtship behaviour in Drosophila. PLoS ONE. 2009; 4:e4457.

26. Kurtovic A, Widmer A, Dickson BJ. A single class of olfactory neurons mediates behavioural responses to a Drosophila sex pheromone. Nature. 2007;446:542-546.

27. Yamamoto D. Brain sex differences and function of the fruitless gene in Drosophila. J Neurogenet. 2008;22:309-332. 
28. Kimura K, Hachiya T, Koganezawa M, Tazawa T, Yamamoto D. Fruitless and doublesex coordinate to generate male-specific neurons that can initiate courtship. Neuron. 2008;59:759-769.

29. Clyne JD, Miesenbock G. Sex-specific control and tuning of the pattern generator for courtship song in Drosophila. Cell. 2008;133. 354-363.

30. Shirangi TR, Dufour HD, Williams TM, Carroll SB. Rapid evolution of sex pheromone producing enzyme expression in Drosophila. PLoS Biol. 2009; 7:e1000168.

31. Ferri SL, Bohm RA, Lincicome HE, et al. Fruitless gene products truncated of their male-like qualities promote neural and behavioural maleness in Drosophila if these proteins are produced in the right places at the right times. $J$ Neurogenet. 2008;22:17-55.

32. Immonen E, Ritchie MG. The genomic response to courtship song stimulation in female Drosophila melanogaster. Proc $R$ Soc Lond B 2012;279:1359-1365.

33. Shirangi TR, Taylor BJ, McKeown M. A double-switch system regulates male courtship behavior in male and female Drosophila melanogaster. Nat Genet. 2006;38:1435-1439.

34. Rideout EJ, Dornal AJ, Neville MC, Eadie S, Goodwin SF. Control of sexual differentiation and behavior by the doublesex gene in Drosophila melanogaster. Nat Neurosci. 2010;13:458-466.

35. Nanda P, Singh BN. Behavioural reproductive isolation and speciation in Drosophila. J Biosci. 2012;37:359-374.

36. Gaertner BE, Ruedi EA, McCoy LJ, Moore JM, Wolfner MF, Mackay TFC. Heritable variation in courtship patterns in Drosophila melanogaster. Genes Genomes Genet. 2015;5:531-539. doi:10.1534/ g3.114.014811.

37. Antony C, Jallon JM. Evolution des hydrocarbures comportementalement actifs des Drosophila melanogaster cours de la maturation sexuelle. C R Acad Sci Paris. 1982;292:239-242.

38. Grillet M, Dartevelle L, Ferveur JF. A Drosophila male pheromone affects female sexual receptivity. Proc Biol Sci. 2006;273:315-323.

39. Marcillac F, Grosjean Y, Ferveur JF. A single mutation alters production and discrimination of Drosophila sex pheromones. Proc R Soc B Lond. 2005;272:303-309.

40. Legendre A, Miao XX, Da Lage JL, Wicker-Thomas C. Evolution of a desaturase involved in female pheromonal cuticular hydrocarbon biosynthesis and courtship behavior in Drosophila. Insect Biochem Mol Biol. 2008;38:244-255.

41. Spiess EB, Langer B. Mating speed control by gene arrangements in Drosophila pseudoobscura homokaryotypes. Proc Natl Acad Sci USA. 1964;51:1015.

42. Clark AG, Feldman MW. The estimation of epistasis in components of fitness in experimental populations of Drosophila melanogaster. II. Assessment of meiotic drive, viability, fecundity and sexual selection. Heredity. 1981;46:347.

43. Singh BN, Chatterjee S. Mating ability of homo- and heterokaryotypes of Drosophila ananassae from natural populations. Heredity. 1986;57:75-78.

44. Singh BN, Chatterjee S. Parallelism between male mating propensity and chromosome arrangement frequency in natural populations of Drosophila ananassae. Heredity. 1988;60:269-272.

45. Sisodia S, Singh BN. Genetics of sexual behaviour in Drosophila. Ind J Exp Biol. 2005;43:575-595.

46. Singh BN, Chatterjee S. Selection for high and low mating propensity in Drosophila ananassae. Behav Genet. 1988;18:357-369.

47. Wolfner MF. Tokens of love: functions and regulation of Drosophila male accessory gland products. Insect Biochem Mol Biol. 1997;27:179-192.

48. Sakai T, Kidokora Y. Overexpression of CREB repressor isoforms enhances the female sexual receptivity in Drosophila. Behav Genet. 2002;32:413.

49. Singh SR, Singh BN. Female remating in Drosophila ananassae. Bidirectional selection for remating speed. Behav Genet. 2001;31:361-370.

50. Prout T, Bundgaard J. The population genetics of sperm displacement. Genetics. 1977;85:95-124.
51. Herrera P, Taylor ML, Skeats A, et al. Can patterns of chromosome inversion in Drosophila pseudoobscura predicts polyandry across a geographical cline? Ecol Evol. 2014;4:3072-3081.

52. Chapman T, Davies SJ. Functions and analysis of the seminal fluid proteins of male Drosophila melanogaster fruit flies. Peptides. 2004;25:1477-1490.

53. Ram KR, Wolfner MF. Sustained post-mating response in Drosophila melanogaster requires multiple seminal fluid proteins. PLoS Genet. 2007;3:e238

54. Ram KR, Wolfner MF. A network of interactions among seminal proteins underlies the long-term postmating response in Drosophila. Proc Natl Acad Sci U S A. 2009;106:15384-15389.

55. Findlay GD, Sitnik JL, Wang W, et al. Evolutionary rate covariation identifies new members of a protein network required for Drosophila melanogaster female post-mating responses. PLoS Genet. 2014;10:e1004108.

56. Fiumera AC, Dumont BL, Clark AG. Sperm competitive ability in Drosophila melanogaster associated with variation in male reproductive proteins. Genetics. 2005;169:243-257.

57. Fiumera AC, Dumont BL, Clark AG. Associations between sperm competition and natural variation in male reproductive genes on the third chromosome of Drosophila melanogaster. Genetics. 2007; $176: 1245-1260$.

58. Reinhart M, Carney T, Clark AG, Fiumera AC. Characterizing malefemale interactions using natural genetic variation in Drosophila melanogaster. J Hered. 2015;106:67-79.

59. Darwin C. The Descent of Man and Selection in Relation to Sex. London: John Murray; 1871.

60. Fisher RA. The Genetical Theory of Natural Selection. Oxford: Clarendon Press; 1930.

61. Lande R. Sexual dimorphism, sexual selection and adaptation in polygenic characters. Evolution. 1980;34:292-305.

62. Amundsen T. Why are female birds ornamented? Trends Ecol Evol. 2000;15:149-155.

63. Zauner H, Begemann G, Mari-Beffa M, Meyer A. Differential regulation of msx genes in the development of the gonopodium, an intromittent organ, and of the "sword," a sexually selected trait of swordtail fishes (Xiphophorus). Evol Dev. 2003;5:466-477.

64. O'Higgins P, Dryden IL. Sexual dimorphism in hominoids: further studies of craniofacial shape differences in Pan, Gorilla and Pongo. J Human Evol. 1993;24:183-205.

65. O'Higgins $\mathrm{P}$, Collard M. Sexual dimorphism and facial growth in papion in monkeys. J Zool Lond. 2002;257:255-272.

66. Leigh SR. Cranial ontogeny of Papio baboons (Papio hamadryas). Am J Phys Anthropol. 2006;130:71-84.

67. Schaefer K, Mitteroecker P, Gunz P, et al. Craniofacial sexual dimorphism patterns and allometry among extant hominids. Ann Anat. 2004;186:471-478.

68. Butler MA, Losos JB. Multivariate sexual dimorphism, sexual selection, and adaptation in Greater Antillean Anolis lizards. Ecol Monogr. 2002;72:541-559.

69. Butler MA, Sawyer SA, Losos JB. Sexual dimorphism and adaptive radiation in Anolis lizards. Nature (Lond). 2007;447:202-205.

70. Malmgren JC, Thollesson M. Sexual size and shape dimorphism in two species of newts, Triturus cristatus and T. vulgaris (Caudata: Salamandridae). J Zool Lond. 1999;249:127-136.

71. Atchley WR. Components of sexual dimorphism in Chironomus larvae (Diptera: Chironomidae). Am Nat. 1971;105:455-466.

72. Lande R, Arnold SJ. Evolution of mating preference and sexual dimorphism. J Theor Biol. 1985;117:651-664.

73. Hedrick AV, Temeles EJ. The evolution of sexual dimorphism in animals hypotheses and tests. Trends Ecol Evol. 1989;4:136-138.

74. Rideout EJ, Goodwin SF. Sexual dimorphism: can you smell the difference? Curr Biol. 2008;18:R425-R426.

75. Jin W, Riley RM, Wolfinger R, et al. The contributions of sex, genotype, and age to transcriptional variance in Drosophila melanogaster. Nat Genet. 2001;29:389-395. 
76. Parisi M, Nuttall R, Naiman D, et al. Paucity of genes on the Drosophila X chromosome showing male-biased expression. Science. 2003;299:697-700.

77. Ranz JM, Castillo-Davis CI, Meiklejohn CD, Hartl DL. Sex-dependent gene expression and evolution of the Drosophila transcriptome. Science. 2003;300:1742-1745.

78. Gibson G, Riley-Berger R, Harshman L, et al. Extensive sex-specific nonadditivity of gene expression in Drosophila melanogaster. Genetics. 2004;167:1791-1799.

79. Carriera VP, Mensch J, Fanara JJ. Body size in Drosophila: genetic architecture, allometries and sexual dimorphism. Heredity. 2009;102:246-256.

80. Taylor ML, Skeats A, Wilson AJ, Price TAR, Wedell N. Opposite environmental and genetic influences on body size in North American Drosophila pseudoobscura. BMC Evol Biol. 2015;15:51.

81. Tsacas L. Une radiation montagnarde: Le groupe dentissima. Rapport d'Activite Scientifique Laboratoire de Biologie et Genetique Evolutives. Gif-sur-Yvette: Centre National de la Recherche Scientifique; 1981:54-56

82. Lakovaara S, Saura A. The obscura group. In: Ashburner M, Carson HL, Thompson JN, editors. The Genetics and Biology of Drosophila. London: Academic Press; 1982:1-59.

83. Lemeunier F, David J, Tsacas L, Ashburner M. The melanogaster species group. In: Ashburner M, Carson H, Thompson J, editors. The Genetics and Biology of Drosophila. London: Elsevier Academic Press; 1986:147-256.

84. Hu YG, Toda MJ. Polyphyly of Lordiphosa and its relationships in Drosophilinae (Diptera: Drosophilidae). Syst Entomol. 2000;25:1-17.

85. Lachaise D, Chassagnard MT. Divergence of sex comb phenotypes in the Drosophila fima species group and radiation on Afrotropical Ficus, including five new species from East Africa and Madagascar (Diptera: Drosophilidae). Annales de la Societe entomologique de France. 2002;38:79-99.

86. Barmina O, Kopp A. Sex-specific expression of a HOX gene associated with rapid morphological evolution. Dev Biol. 2007;311:277-286.

87. Spieth HT. Mating behavior within the genus Drosophila (Diptera). Bull Am Mus Nat Hist. 1952;99:395-474.

88. Kennison JA, Russell MA. Dosage-dependent modifiers of homeotic mutations in Drosophila melanogaster. Genetics. 1987;116:75-86.

89. Boube M, Benassayag C, Seroude L, Cribbs DL. Ras1-mediated modulation of Drosophila homeotic function in cell and segment identity. Genetics. 1997;146:619-628.

90. Pattatucci AM, Otteson DC, Kaufman TC. A functional and structural analysis of the sex combs reduced locus of Drosophila melanogaster. Genetics. 1991;129:423-441.

91. Baker BS, Ridge KA. Sex and the single cell: on the action of major loci affecting sex determination in Drosophila melanogaster. Genetics. 1980;94:383-423.

92. Li H, Baker BS. Hermaphrodite and doublesex function both dependently and independently to control various aspects of sexual differentiation in Drosophila. Development. 1998;125:2641-2651.

93. Waterbury JA, Jackson LL, Schedl P. Analysis of the doublesex female protein in Drosophila melanogaster: role on sexual differentiation and behavior and dependence on intersex. Genetics. 1999; 152:1653-1667.

94. Burtis KC, Coschigano KT, Baker BS, Wensink PC. The doublesex proteins of Drosophila melanogaster bind directly to a sex-specific yolk protein gene enhancer. EMBO J. 1991;10:2577-2582.

95. Narendra U, Zhu L, Li B, Wilken J, Weiss MA. Sex-specific gene regulation. The Doublesex DM motif is a bipartite DNA-binding domain. J Biol Chem. 2002;277:43463-43473.

96. Jursnich VA, Burtis KC. A positive role in differentiation for the male doublesex protein of Drosophila. Dev Biol. 1993;155:235-249.

97. Clough E, Jimenez E, Kim YA, et al. Sex and tissue-specific functions of Drosophila doublesex transcription factor target genes. Dev Cell. 2014;31:761-773.
98. Couderc JL, Godt D, Zollman S, et al. The bric a brac locus consists of two paralogous genes encoding BTB/POZ domain proteins and acts as a homeotic and morphogenetic regulator of imaginal development in Drosophila. Development. 2002;129:2419-2433.

99. Galindo MI, Bishop SA, Greig S, Couso JP. Leg patterning driven by proximal-distal interactions and EGFR signaling. Science. 2002;297:256-259.

100. True JR, Insect melanism: the molecules matter. Trends Ecol Evol. 2003;18:640-647.

101. Wittkopp PJ, Carroll SB, Kopp A. Evolution in black and white: genetic control of pigment patterns in Drosophila. Trends Genet. 2003;19:495-504.

102. Wittkopp PJ, Beldade P. Development and evolution of insect pigmentation: genetic mechanisms and the potential consequences of pleiotropy. Semin Cell Dev Biol. 2009;20:65-71.

103. Kronforst MR, Barsh GS, Kopp A, et al. Unraveling the thread of nature's tapestry: the genetics of diversity and convergence in animal pigmentation. Pigm Cell Melan Res. 2002;25:411-433.

104. Bock IR, Wheeler MR. The Drosophila melanogaster species group. Univ Texas Publ. 1972;7213:1-102.

105. Llopart A, Elwyn S, Lachaise D, Coyne JA. Genetics of a difference in pigmentation between Drosophila yakuba and Drosophila santomea. Evolution. 2002;56:2262-2277.

106. Ng CS, Hamilton AM, Frank A, Barmina O, Kopp A. Genetic basis of sex-specific color pattern variation in Drosophila malerkotliana. Genetics. 2008;180:421-429.

107. Jeong S, Rebeiz M, Andolfatto P, et al. The evolution of gene regulation underlies a morphological difference between two Drosophila sister species. Cell. 2008;132:783-793.

108. Lours C, Bardot O, Godt D, Laski FA, Couderc JL. The Drosophila melanogaster BTB proteins bric a brac bind DNA through a composite DNA binding domain containing a pipsqueak and an AT-Hook motif. Nucl Acids Res. 2003;31:5389-5398.

109. Kopp A, Duncan I, Godt D, Carroll SB. Genetic control and evolution of sexually dimorphic characters in Drosophila. Nature. 2000;408:553-559.

110. Williams TM, Selegue JE, Werner T, et al. The regulation and evolution of a genetic switch controlling sexually dimorphic traits in Drosophila. Cell. 2008;134:610-623.

111. Dembeck LM, Huang W, Magwire MM, et al. Genetic architecture of abdominal pigmentation in Drosophila melanogaster. PLoS Genet. 2015;11:e1005163.

112. Wright TR. The genetics of biogenic amine metabolism, sclerotization, and melanization in Drosophila melanogaster. Adv Genet. $1987 ; 24: 127-222$

113. Han Q, Fang J, Ding H, et al. Identification of Drosophila melanogaster yellow-f and yellow-f2 proteins as dopachrome-conversion enzymes. Biochem J. 2002;368:333-340.

114. True JR, Yeh SD, Hovemann BT, et al. Drosophila tan encodes a novel hydrolase required in pigmentation and vision. PLoS Genet. 2005; 1:e63.

115. Kraminsky GP, Clark WC, Estelle MA, et al. Induction of translatable mRNA for dopa decarboxylase in Drosophila: an early response to ecdysterone. Proc Natl Acad Sci U S A. 1980;77:4175-4179.

116. Walter MF, Black BC, Afshar G, et al. Temporal and spatial expression of the yellow gene in correlation with cuticle formation and dopa decarboxylase activity in Drosophila development. Dev Biol. 1991; 147:32-45.

117. Futahashi R, Fujiwara H. Melanin-synthesis enzymes coregulate stage-specific larval cuticular markings in the swallowtail butterfly, Papilio xuthus. Dev Genes Evol. 2005;215:519-529.

118. Ninomiya Y, Tanaka K, Hayakawa Y. Mechanisms of black and white stripe pattern formation in the cuticles of insect larvae. J Insect Physiol. 2006;52:638-645.

119. Kopp A, Barmina O. Evolutionary history of the Drosophila bipectinata species complex. Genet Res. 2005;85:23-46. 
120. Arnoult L, Su KF, Manoel D, et al. Emergence and diversification of fly pigmentation through evolution of a gene regulatory module. Science. 2013;339:1423-1426.

121. Hegde SN, Chethan BK, Krishna MS. Mating success of males with and without wing patch in Drosophila biarmipes. Ind J Exp Biol. 2005;43:902-909.

122. Takahashi A. Pigmentation and behavior: potential association through pleiotropic genes in Drosophila. Genes Genet Syst. 2013;88:165-174.

123. Yassin A, Orgogozo V. Coevolution between male and female genitalia in the Drosophila melanogaster species subgroup. PLoS ONE. 2013;8:e57158.

124. Kyriacou CP, Hall JC. Genetic and molecular analysis of Drosophila behavior. Adv Genet. 1994;31:139-186.

125. Dubnau J, Tully T. Gene discovery in Drosophila: new insights for learning and memory. Annu Rev Neurosci. 1998;21:407-444.

126. Freeman M. Reiterative use of the EGF receptor triggers differentiation of all cell types in the Drosophila eye. Cell. 1996;87:651-660.

127. Brand AH, Perrimon N. Targeted gene expression as a means of altering cell fates and generating dominant phenotypes. Development. 1993;118:401-415.

128. Ferveur JF, Störtkuhl KF, Stocker RF, Greenspan RJ. Genetic feminization of brain structures and changed sexual orientation in male Drosophila. Science. 1995;267:902-905.

129. Connolly K, Tunnicliff G, Rick JT. The effects of g-hydroxybutyric acid on spontaneous locomotor activity and dopamine level in a selected strain of Drosophila melanogaster. Comp Biochem Physiol. 1971;40:321-326.
130. Joiner MA, Griffith LC. Mapping of the anatomical circuit of CaM kinase-dependent courtship conditioning in Drosophila. Learn Mem. 1999;6:177-192.

131. Bernstein BE, Birney E, Dunham I, et al. An integrated encyclopedia of DNA elements in the human genome. Nature. 2012;489:57-74.

132. Yamamoto D, Koganezawa M. Genes and circuits of courtship behavior in Drosophila males. Nat Rev Neurosci. 2013;14:681-692.

133. Duffy JB. GAL4 system in Drosophila: a fly geneticist's Swiss army knife. Genesis. 2002;34:1-15.

134. Bassett AR, Tibbit C, Ponting CP, Liu JL. Highly efficient targeted mutagenesis of Drosophila with the CRISPR/Cas9 system. Cell Rep. 2013;4:220-228.

135. Gratz SJ, Cummings AM, Nguyen JN, et al. Genome engineering of Drosophila with the CRISPR RNA-guided Cas9 nuclease. Genetics. 2013;194:1029-1035.

136. Kondo S, Ueda R. Highly improved gene targeting by germline specific Cas9 expression in Drosophila. Genetics. 2013;195:715-721.

137. Ren X, Sun J, Housden BE, et al. Optimized gene editing technology for Drosophila melanogaster using germ line-specific Cas9. Proc Natl Acad Sci U S A. 2013;110:19012-19017.

138. Sebo ZL, Lee HB, Peng Y, Guo Y. A simplified and efficient germlinespecific CRISPR/Cas9 system for Drosophila genomic engineering Fly (Austin). 2014;8:52-57.

139. Yu Z, Ren M, Wang Z, et al. Highly efficient genome modifications mediated by CRISPR/Cas9 in Drosophila. Genetics. 2013;195:289-291.
Advances in Genomics and Genetics

\section{Publish your work in this journal}

Advances in Genomics and Genetics is an international, peer reviewed, open access journal that focuses on new developments in characterizing the human and animal genome and specific gene expressions in health and disease. Particular emphasis will be given to those studies that elucidate genes, biomarkers and targets in the development of new or improved therapeutic

\section{Dovepress}

interventions. The journal is characterized by the rapid reporting of reviews, original research, methodologies, technologies and analytics in this subject area. The manuscript management system is completely online and includes a very quick and fair peer-review system. Visit http://www.dovepress.com/ testimonials.php to read real quotes from published authors. 